\title{
Peritubular Myoid Cells in the Testis: Their Structure and Function*
}

\author{
Mamiko Maekawa, Kyoko Kamimura and Toshio Nagano \\ Department of Anatomy, Chiba University School of Medicine, Chiba, Japan
}

Received January 16, 1996

\begin{abstract}
Summary. Peritubular myoid cells, surrounding the seminiferous tubules in the testis, have been found in all mammalian species, but their organization in the peritubular interstitial tissue varies by species. In laboratory rodents, including rats, hamsters and mice, only one layer of myoid cells is seen in the testis. The cells in these animals are joined by junctional complexes as are epithelial cells. On the other hand, several cellular layers exist in the lamina propria of the seminiferous tubule in the human and some other animals. Myoid cells contain abundant actin filaments which are distributed in the cells in a species-specific manner. In the rat, the filaments within one myoid cell run both longitudinally and circularly to the long axis of the seminiferous tubule, exhibiting a lattice-work pattern. The arrangement of the actin filaments in the cells changes during postnatal development, and the disruption of spermatogenesis, such as cryptorchidism, seems to affect further the arrangement of the filaments. Other cytoskeletal proteins, including myosin, desmin/vimentin and $\alpha$-actinin, are also found in the cells. Myoid cells have been shown to be contractile, involved in the transport of spermatozoa and testicular fluid in the tubule. Several substances (prostaglandins, oxytocin, TGF $\beta$, NO/cGMP) have been suggested to affect the contraction of the cell, though the mechanisms of the contraction are still unknown. Recent in vitro studies have demonstrated that the cells secrete a number of substances including extracellular matrix components (fibronectin, type I and IV collagens, proteoglycans) and growth factors (PModS, TGF $\beta$, IGF-I, activin-A). Some of these substances are known to affect the Sertoli cell function. Furthermore, it has been reported that myoid cells contain androgen receptors and are involved in retinol processing. Considering all this, it is evident that peritubular myoid cells not only provide structural integrity to the tubule but also take part in
\end{abstract}

the regulation of spermatogenesis and the testicular function. Their precise roles, however, remain to be solved.

In 1901, REGAUD observed a continuous single layer of flattened cells surrounding the seminiferous tubule in the rat, and described these cells as modified connective tissue cells. The cells were investigated further by electron microscopy by CLERMONT (1958). He found that these cells of the rat contain a dense meshwork of extremely fine filaments. In addition to the existence of the cytoplasmic filaments, other cytological features such as invaginations at the cell surface and a central location of organelles, indicate that the cells are similar to smooth muscle cells. Before this observation, RoOSEN-RUNGE (1951) reported contractile motions of the seminiferous tubules of the rat and dog, and attributed these to the Sertoli cells. However, Clermont (1958) showed that portions of a gently squeezed tubule, which had been freed from germinal cells and Sertoli cells, still exhibited a periodic contraction. He concluded that the smooth muscle-like cells, which he designated "interlamellar cells", were responsible for the tubular contraction. The fine structure of these cells in the mouse was studied by Ross (1967), who referred to the cells as "peritubular contractile cells". FAWCETT et al. (1969) introduced the term "myoid cells" based on their cytological resemblance to smooth muscle cells at the electron microscope level.

\footnotetext{
${ }^{*}$ This work was supported by a Grant-in-Aid for Scientific Research from the Ministry of Education, Science and Culture, Japan (Nos. 06670008 and 06670009).
} 


\section{STRUCTURE}

\section{Species-specific differences}

Arrangements of testicular intertubular (interstitial) tissues differ from species to species. Comparative studies on the organizations of the interstitial tissue have classified three or four patterns according to the occupied space of lymphatics, blood capillaries, Leydig cells and connective tissue cells (FAWCETT, 1973; FAWCETT et al., 1973). The postnatal development of the boundary tissue of the seminiferous tubule has been investigated in the mouse (Ross, 1967), rat (LEESON and Leeson, 1963; Kormano and Hovatta, 1972; PAlombi et al., 1992), sheep (Bustos-Obregon and COUROT, 1974), rabbit (LEESON and FORMAN, 1981), and bull (WroBel et al., 1988).

The organization of the myoid cell layers also dif-

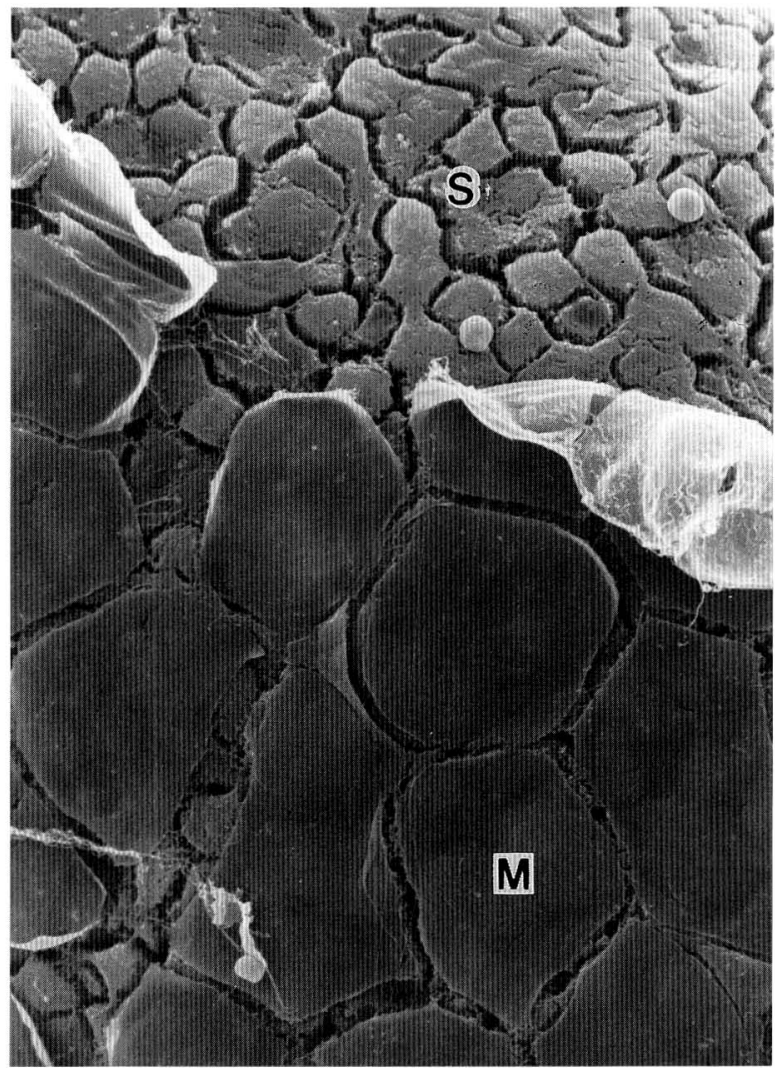

Fig. 1. SEM image of the mouse seminiferous tubule. The basal lamina and connective tissues have been digested by alkaline treatments. Consequently, some myoid cells have been taken away and intercellular spaces widened. A single layer of flat myoid cells $(M)$ is shown. The basal aspect of the seminiferous epithelium (S) is seen. $\times 740$ (Courtesy of Prof. T. UsHiki). fers among species (Bustos-OBREGON, 1976; Christ L, 1990). Laboratory rodents including rats (LACY and Rotblat, 1960), mice (GARDNer and Holyoke, 1964; Ross, 1967) and hamsters (MCCORD, 1970) have a single layer of myoid cells (Figs. 1, 2). The rat myoid cells have been imaged by scanning electron microscopy, applying the digestion method for connective tissues (Murakami et al., 1979). It is obvious that the myoid cells are very thin, flattened elements with shapes varying from rectangular to hexagonal (Fig. 1). The cells are arranged close to each other in the fashion of a tiled floor around the tubule.

In larger animals, such as the rabbit (CRABO, 1963; LEESON and FORMAN, 1981), ram (BUSTOS-OBREGON and Courot, 1974), bull (Wrobel et al., 1979) and in humans (Ross and LONG, 1966), myoid cells are arranged as more than one layer. Five to seven cellular layers, each separated by extracellular connective tissue, were found in the lamina propria of the human seminiferous tubule (Bustos-OBREGON and HOLSTEIN, 1973; Bustos-Obregon, 1976; Holstein and RoOsenRunge, 1981). Among these cellular layers, immunohistochemical studies have shown that the outer one or two layers of the lamina propria consist of fibroblasts, as shall be discussed later (DAvidoff et al., 1990). The myoid cells in the human testis additionally possess characteristics of fibroblasts, and therefore are designated as myofibroblasts (Böck et al., 1972). The heterogeneity of these cells of the human seminiferous tubule has been reported by HoLsTEIN et al. (1996). Myoid cells are derived from mesenchymal cells, as are Leydig cells and fibroblasts. An ultrastructural study has suggested that, in human testis, myoid cells may develop into Leydig cells (Christensen, 1975).

Smooth muscle-like peritubular cells also have been reported in the domestic fowl (RoTHWELl and TINGARI, 1973), quail (VAN NASSAUw et al., 1993) and reptilian testes (UNSICKER and BURNSTOCK, 1975). However, three species of anuran amphibia lack a peritubular layer of myoid cells comparable to that in the mammalian testis (UNSICKER, 1975). The widespread occurrence of myoid cells among various species suggests the importance of these cells in the testis.

\section{Actin filaments in the myoid cells}

Abundant filaments observed in the myoid cells were found to be actin filaments, and the opposing polarity of the filaments was seen using heavy meromyosin decorations (TOYAMA, 1977). Actin filaments are also abundant in ectoplasmic specializations of Sertoli cells and Sertoli cell regions adjacent to the tubulo- 


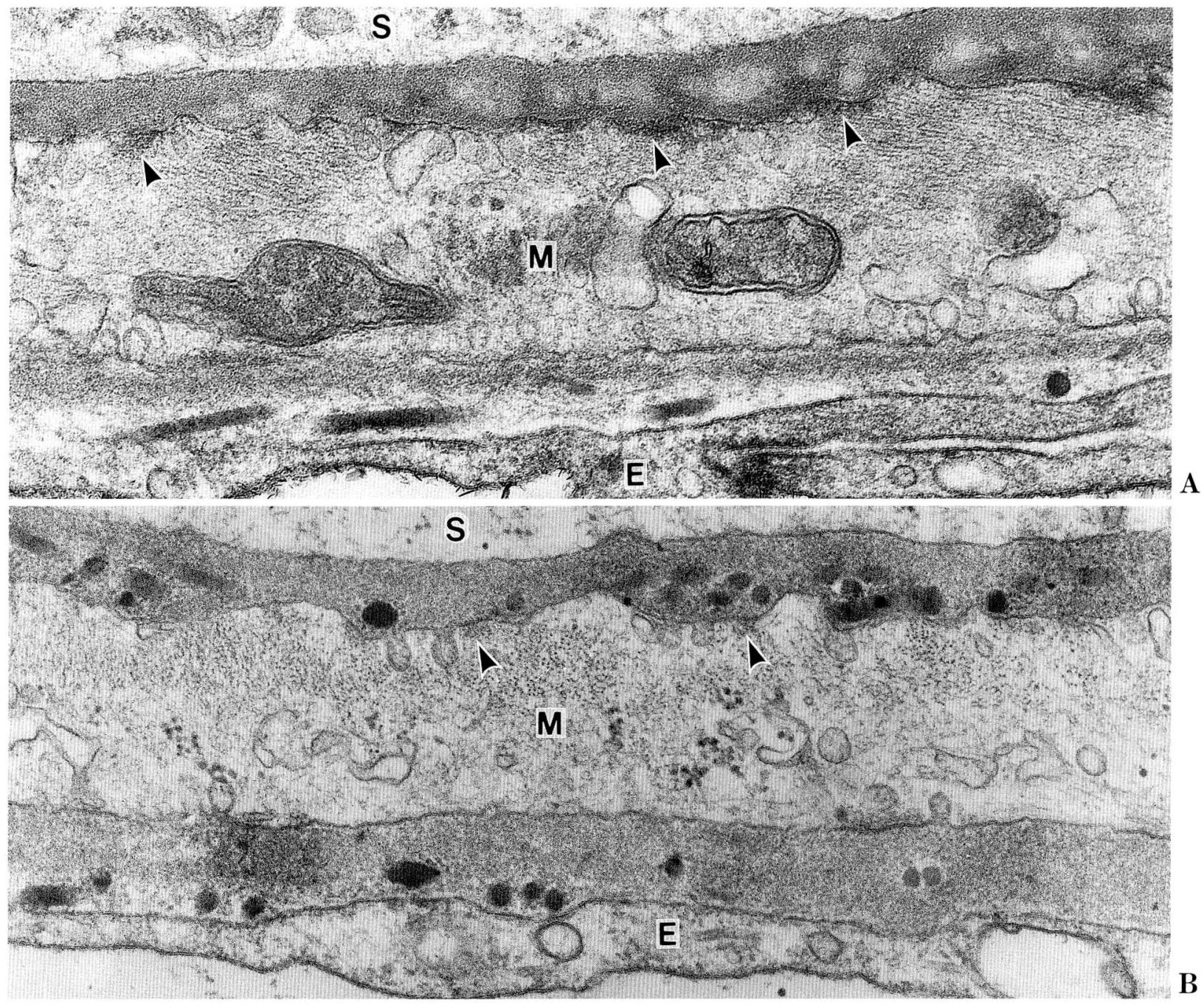

Fig. 2. Electron micrograph of the basal part of the rat seminiferous tubule. The myoid cell contains actin filaments cut obliquely (A) and transversally (B). Dense materials beneath the plasma membrane can be seen (arrowheads). The tissue was processed as usual with tannic acid treatment during aldehyde fixation. A taken at $350 \mathrm{kV} . S$ seminiferous epithelium, $M$ myoid cell, $E$ endothelial cell of a lymphatic vessel. A: $\times 54,000, \mathrm{~B}$ : $\times 58,000$

bulbar complex within the seminiferous epithelium (VOGL and Soucy, 1985; Vogl, 1989). Among several actin isoforms, $\alpha$-smooth muscle isoactin can be detected only in the myoid cells and vascular smooth muscle cells, and not in other cell types of the rat testis (Tung and FriTz, 1990). Alpha-smooth muscle actin could be used as a specific marker for the differentiation of testicular myoid cells in the monkey (SchlatT et al., 1993).

With the use of fluorescence-labeled phallotoxins for the detection of the actin filaments, it has been revealed that myoid cells have a special arrangement of actin filament bundles in the ground squirrel (VOGL and Soucy, 1985) and rat (Vogl et al., 1985; Russell et al., 1989). In these animals actin-filament bundles run in different directions within one myoid cell. The bundles are oriented in two directions-parallel (longitudinal) and perpendicular (circular) to the long axis of the tubule. Since the myoid cells have been described as very thin, denuded tubule walls could be used to demonstrate actin filaments of the cells in the previous studies (VOGL and SOUCY, 1985; VoGL et al., 1985; RuSSELL et al., 1989).

The recent development of confocal laser microscopy has enabled to observe whole-mounted seminiferous tubules. Using this method, we examined the 


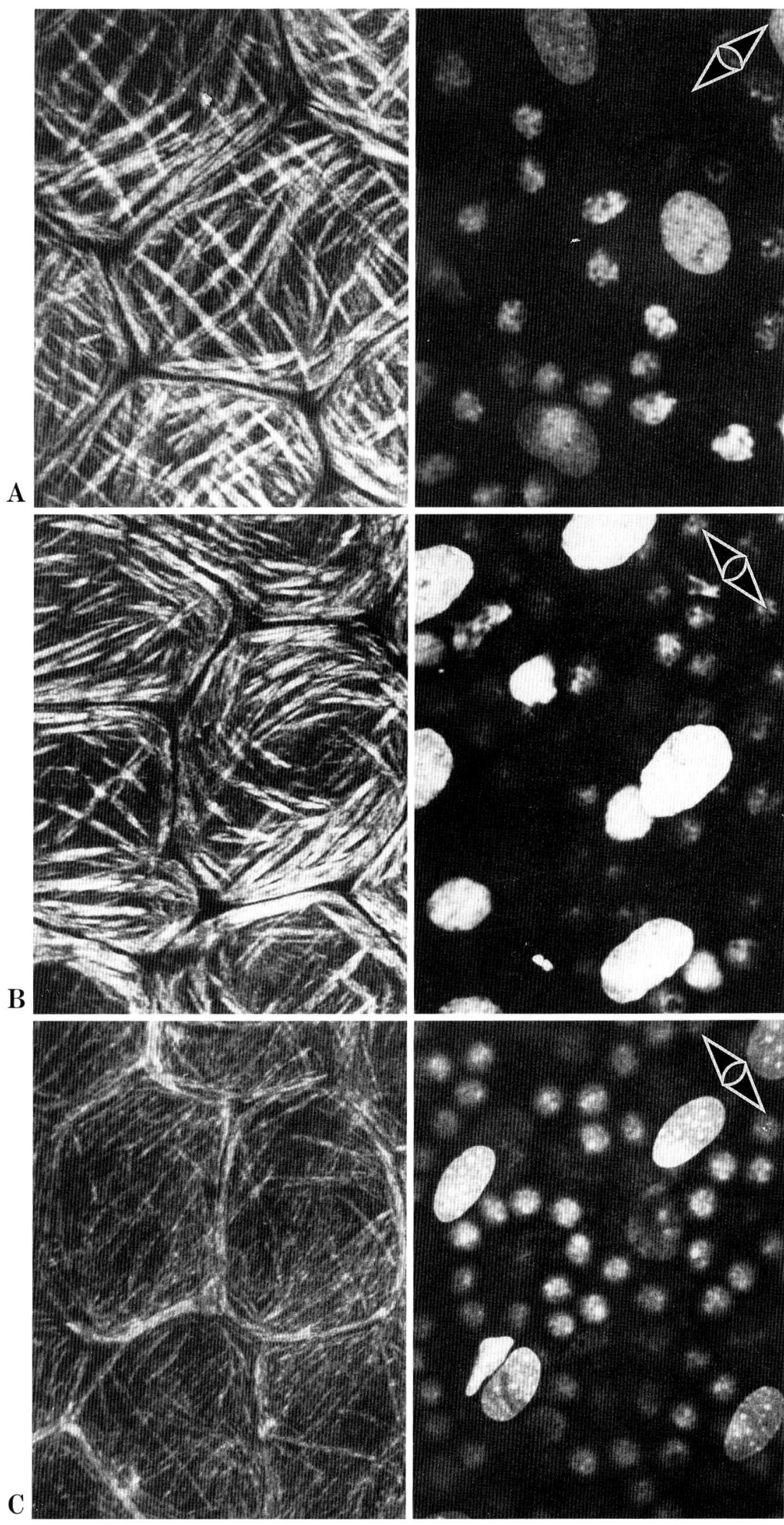

Fig. 3. Confocal images of isolated seminiferous tubules of the rat (A), golden hamster (B) and mouse (C), double-stained with NBD-labeled phallacidin (left) and propidium iodide (right). Actin filament bundles in the myoid cells are shown on the left. Elliptic nuclei of the myoid cells stained with propidium iodide are shown on the right. Note that their long diameter is perpendicular to the tubular axis (arrowheads). $\times 700$ (from MAEKAWA et al., 1994) 
arrangement of actin filaments in the rat, golden hamster and mouse testes (MAEKAWA et al., 1991, 1994, 1995). These rodents have a single layer of myoid cells; differences among the three species could be visualized in the arrangement of actin-filament bundles in these cells (Fig. 3). The rat testis shows the most prominent lattice-work arrangement of the filament, running circularly and longitudinally to the tubule. In the golden hamster, filament bundles running circularly around the tubule are more prominent than longitudinally oriented ones. In the myoid cells of the mouse, the actin-filament bundles are thinner than in the rat and hamster and show a less prominent lattice-work. The special arrangement of the filaments appears to play an important role in the movements of the cells. It is speculated that the differences in the distribution pattern of actin filaments among the three species might imply speciesspecific contractile movements of the tubule. Nuclei of the myoid cells are elliptic in shape, showing a tendency to be elongated in a circular direction in the tubule (Fig. 3). In the human testis, where several layers of myoid cells (myofibroblasts) are found as described above, the morphology of the cell is highly complicated. HoLsTEIN et al. (1996) have observed that the cell has bilayered peripheral cell bodies, and that the actin filaments in different cytoplasmic layers of one myofibroblast run in different directions. The complex organization in the human testis might reflect the delicate control of the contraction. and/or other function of the cell.

Morphometric analysis of the myoid cells by confocal microscopy has been carried out in the three species of rodents (MAEKAWA et al., 1994). Since the staining of actin filaments reveals the contours of the cells, their area can be calculated by tracing the contours. The highest mean value of the myoid cell area was obtained in the golden hamster $(2686 \pm 98$ $\left.\mathrm{mm}^{2}\right)$, then the rat $\left(2218 \pm 80 \mathrm{~mm}^{2}\right)$, and the lowest in the mouse $\left(1782 \pm 45 \mathrm{~mm}^{2}\right)$. The cell surface area of the myoid cell in the golden hamster has also been obtained by use of quantitative electron microscopy (KUROHMARU et al., 1990), and their result (1908 \pm 605 $\mathrm{mm}^{2}$ ) was smaller than ours.

\section{Changes in the arrangement of actin filaments during postnatal development and in experimental conditions}

In the rat myoid cells, contractile filaments appear at the age of 10 days (LEESON and LEESON, 1963) or 15 days (KoRMANO and HovATTA, 1972), and myoid cells mature in morphology by 22 days (LEESON and LEESON, 1963) or 25 days (Kormano and HovatTA, 1972). The arrangement of the actin filaments changes during postnatal development. According to Russell et al. (1989), parallel actin filaments are present at 10 days, and by 22 days actin filaments form an adult-like meshwork pattern. In our recent study (MAEKAWA et al., 1995), only circular bundles of actin filaments were seen in the rat myoid cells at 15 days of age, and longitudinal bundles appeared at 30 days. The lattice arrangement of the actin filaments was completed at 40 days, when elongated spermatids occurred in the seminiferous epithelium. These data suggest that the myoid cells may mature morphologically before the completion of spermatogenesis.

It is well known that the induction of experimental cryptorchidism results in the disruption of spermatogenesis by high abdominal temperature (MOORE, 1924). Cryptorchidism also affects myoid cells morphologically (KERR et al., 1979). Seven days after abdominal confinement, the arrangement of actin filaments in the rat myoid cells shows a remarkable disruption (MAEKAWA et al., 1995). KUROHMARU et al. (1990) have reported changes in structure of myoid cells during inactive states of spermatogenesis in the golden hamster. They also have noted that actin filaments do not seem so prominent in inactive animals as in active ones. These results suggest that actin filament arrangements in the myoid cell may reflect spermatogenic activity.

\section{Other cytoskeletal proteins in the myoid cell}

In addition to actin, myoid cells also contain other cytoskeletal proteins. Myosin filaments are immunolocalized in a fashion similar to the distribution of the actin filaments in the myoid cells of the ground squirrel (VOGL and SOUCY, 1985), and rat and human (VIRTANEN et al., 1986). Intermediate filaments have been recognized in the swine and mouse myoid cells by an ultrastructural study (ToyAma, 1975). Desmin, a muscletype protein of intermediate filaments, has been immunolocalized in myoid cells of the human (VIRTANEN et al., 1986; MARTIN et al., 1992; KoHNEN et al., 1995) and rat (VIRTANEN et al., 1986; PALOMBI et al., 1992; PARANKo and PELliniemi, 1992). However, STEGER et al. (1994) have demonstrated that the myoid cells of the bull and ram do not contain desmin, but instead show vimentin, which is abundant in fibroblasts. These results might reflect species-specific differences in the degree of differentiation from fibroblasts to smooth muscle cells in the myoid cell population (BUSTOSOBREGON and COUROT, 1974; LEESON and FORMAN 1981; Wrobel et al., 1979, 1988). DAVIDOFF et al. (1990) have reported that the inner three to four cellular layers in the lamina propria of the human seminiferous tubule 

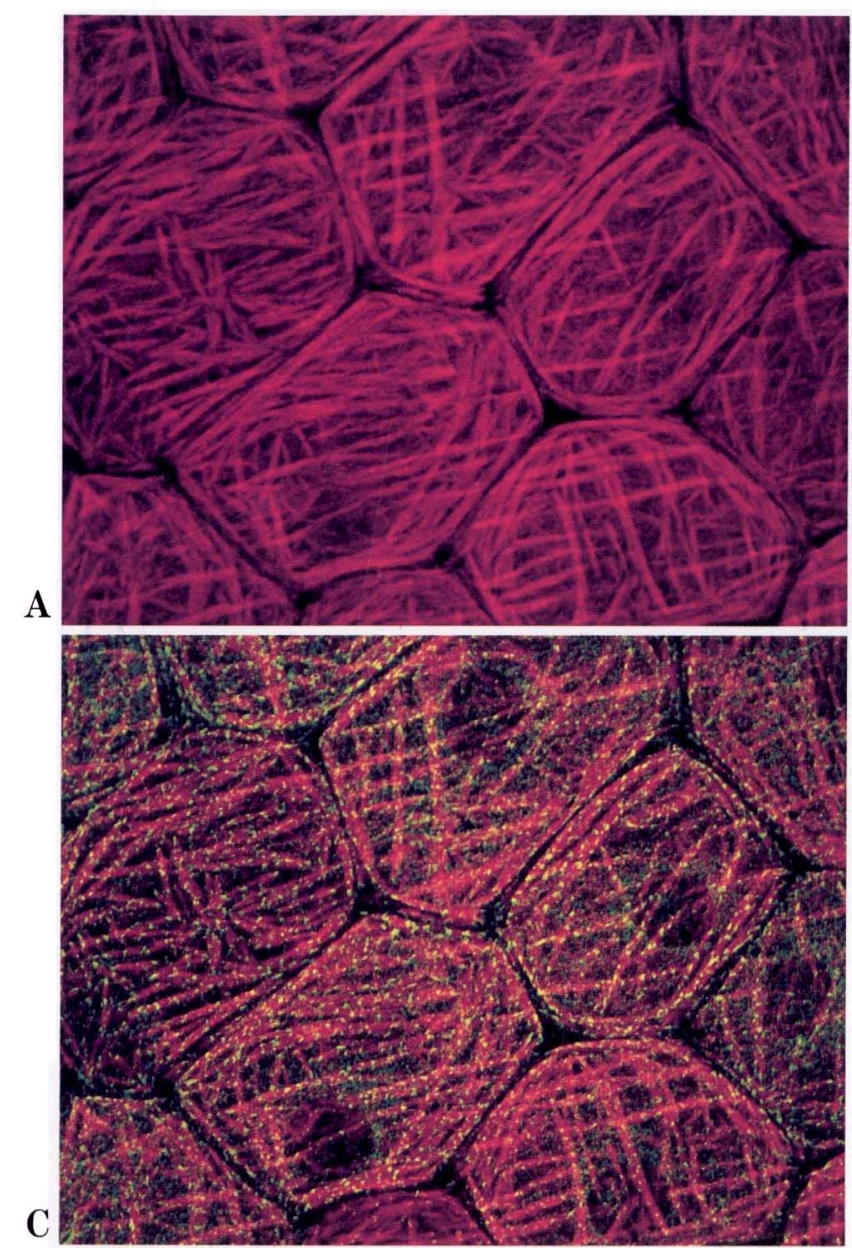

show immunoreactivity for both desmin and vimentin, whereas the outermost one or two cellular layers have immunoreactivity only for vimentin. They therefore concluded that the outer layer(s) are true fibroblasts. In human subjects with Klinefelter's syndrome, desmin-containing peritubular cells decrease, while the vimentin-containing cells increase with the progression of sclerosis in the lamina propria of the seminiferous tubule (MARTIN et al., 1992).

One of the actin-binding proteins, $\alpha$-actinin, has been immunolocalized in the rat myoid cells by confocal laser microscopy (Fig. 4) and immuno-electron microscopy (Fig. 5). This protein is distributed as dots in the actin filament bundles of the myoid cells (Fig. 4), and seems to exist in dense bodies of the myoid cell (Fig. 5). These results correspond to other reports showing the existence of the $\alpha$-actinin in dense bodies of smooth muscle cells in the chicken gizzard (GEIGER et al., 1981) and in stomach muscle layers (FAY et al., 1983). Another cytoplasmic protein, vinculin, which interacts with actin (MENKEL et al.,
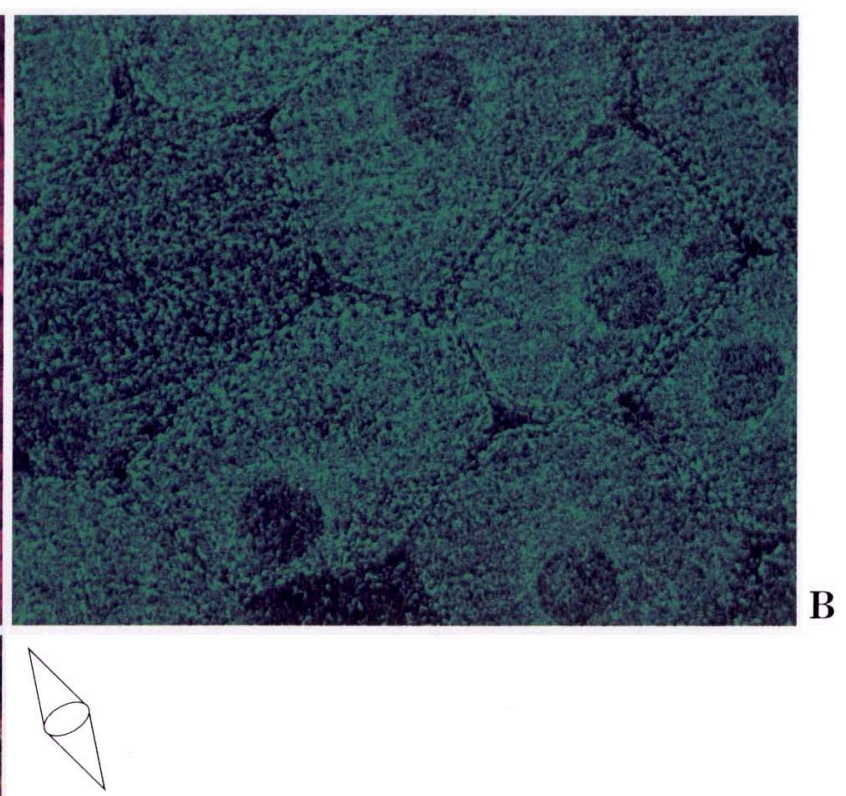

Fig. 4. Confocal images of myoid cells from the isolated seminiferous tubule of the rat, double-stained with TRITC-labeled phalloidin (A) and anti- $\alpha$-actinin antibody (B). C. A superimposed image of $\mathbf{A}$ and $\mathbf{B}$. Alpha-actinin-positive dots are shown in the actin filaments. The arrowheads indicate the axis of the tubule. $\times 600$

1994) and $\alpha$-actinin (BELKIN and Koteliansky, 1987 ; WACHSSTOCK et al., 1987), is also detectable in the rat myoid cells by immunofluorescence staining (GROVE and VoGL, 1989; Grove et al., 1990).

\section{FUNCTION}

\section{Blood-testis barrier}

Myoid cells are known to act as a partial permeability barrier to help create the blood-testis barrier (DYM and FAWCETT, 1970). The morphological basis of the blood-testis barrier was examined with the electron microscope by FAWCETT et al. (1970). Large tracers, carbon and thorium dioxide, are unable to traverse the myoid cell layer in the guinea pig, whereas smaller markers such as ferritin and peroxidase are not completely excluded (FAWCETT et al., 1970). In the rat, occluding junctions exist between adjacent myoid cells to prevent the passage of lanthanum into the 


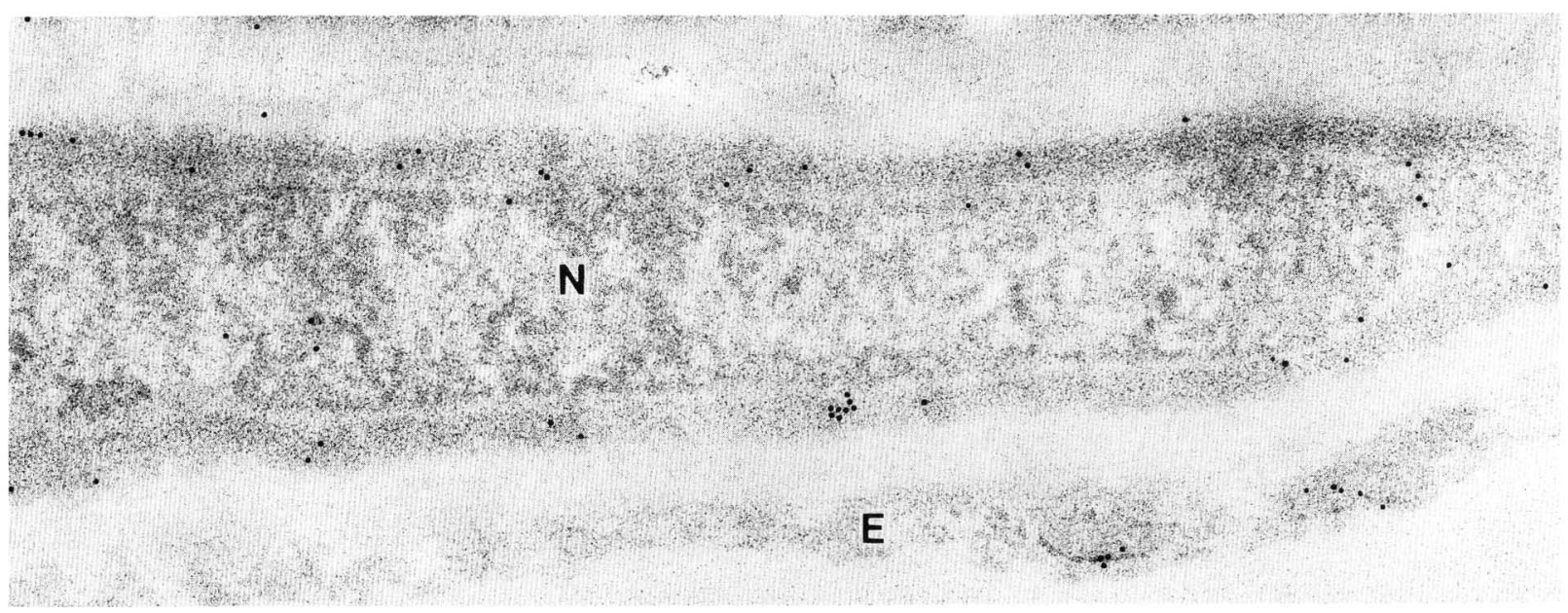

Fig. 5. Immunogold electron micrograph of the rat myoid cell embedded in Lowicryl and stained with anti- $\alpha$-actinin antibody. The particles are seen in the dense bodies. $E$ endothelial cell, $N$ nucleus of the myoid cell. $\times 45,000$

germinal epithelium (Dym and FAwCETT, 1970). However, some of the junctional complex exhibit a continuous intercellular space of $200 \AA$, and permit the penetration of the tracer at these sites (Dym and FAwCETT, 1970). Therefore, peritubular myoid cells serve as a part of the barrier to the penetration of substances into the germinal epithelium, although Sertoli cell junctions have a principal role in the barrier. However, in the monkey testis with its several layers of myoid cells, tracers readily pass between the cells as occluding junctions seem to be absent between the myoid cells (DYM, 1973).

\section{Contraction}

Myoid cells play a role in contractions of the seminiferous tubule to aid the transport of spermatozoa in the tubular lumen. Since RoOSEn-RUnGe (1951) first reported the motility of the seminiferous tubules of rats and dogs, the contractility of myoid cells has been studied in vitro, including in the human (MrYAKE et al., 1986). Several substances, including prostaglandins (YАмамото et al., 1987), transforming growth factor $\beta$ (TGF $\beta$ ) (AILENBERG et al., 1990), endothelin (FILIPPINI et al., 1993) and the NO/cGMP system (DAvidofF et al., 1995; Holstein et al., 1996), have been shown to affect the contractions of seminiferous tubules. Exogenous oxytocin also stimulates the contraction of isolated seminiferous tubules (NIEMI and KORMANO, 1965), although no oxytocin receptors have been detected on myoid cells (PICKERING et al., 1989). Recently, Howl et al. (1995) have demonstrated that myoid cells in the adult rat express vasopressin receptors, and suggested that the effect of oxytocin must have been due to the oxytocin-induced activation of vasopressin receptors on the myoid cells. The mechanisms involved in the modulation of the tubular contractility are unknown. Immunohistochemical studies indicate no innervation to the myoid cells in the rat testis (CARVALHO et al., 1986; NAGANO et al., 1994). This fact suggests that the contractility of the seminiferous tubule might be regulated by paracrine actions of the substances mentioned above.

Kormano and HovatTa (1972) have reported that in vitro contractility of the seminiferous tubules of the rat is detected at the age of 15 days when the actin filaments first appear, and that the depth of the contraction increases up to 60 days, when sexually matured. Contractility may be associated with the cyclic stages of the seminiferous epithelium in the rat (Suvanto and Kormano, 1970). They have observed both contractile and non-contractile segments of the seminiferous tubules in vitro, and during stages IV to VII, in which maturing spermatids begin to move towards the lumen, the ratio of number of contractile to non-contractile segments is relatively high, compared to other stages.

We recently observed the spontaneous contraction of the seminiferous tubule in vivo, using adult rats anesthetized with halothane under the respiration and temperature controls (NAGANO et al., 1994). In this system, changes in the internal pressure of the tubule are also detectable (Fig. 6), due to the movement of the internal content, namely spermatozoa and testicular fluid. The frequency of the pressure change in the seminiferous tubule is $0.17-0.23 \mathrm{~Hz}$, and is lower than that of epididymal ducts where several muscle layers and rich innervation are present 
A

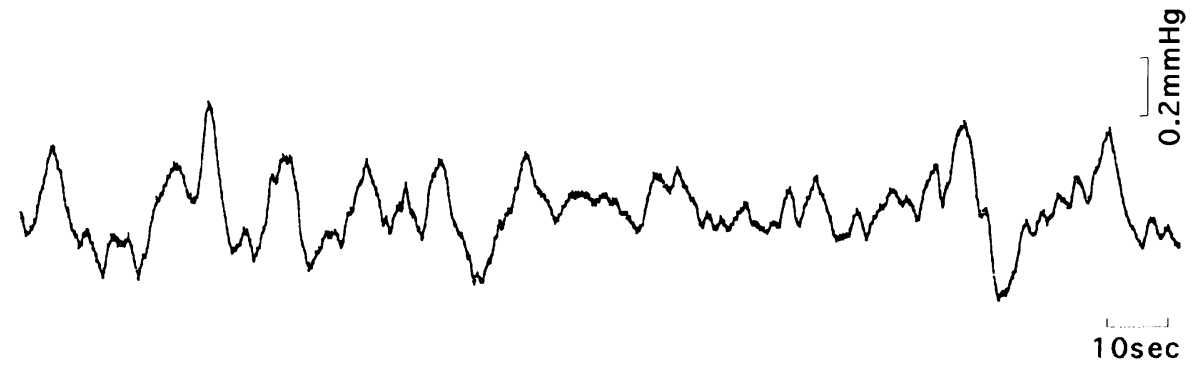

B

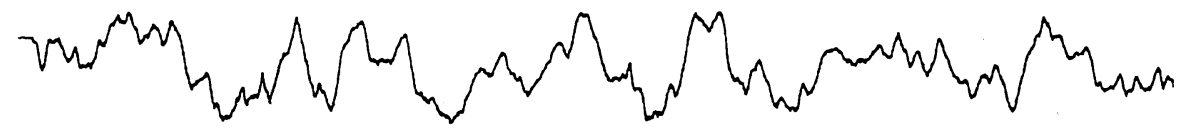

C

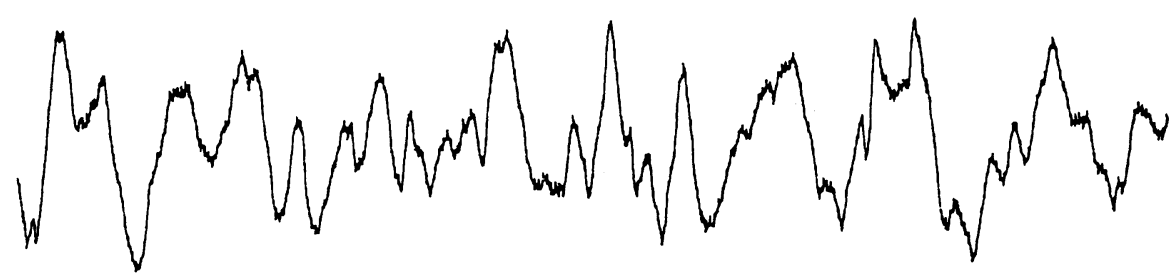

Fig. 6. Changes in the luminal pressure of the seminiferous tubule and epididymal ducts from the adult rat anesthetized with halothane under respiration and temperature controls. The testis and epididymis have been exposed, and a glass pipette connected with a manometic apparatus inserted into the tubule. A: Seminiferous tubule, B: Epididymal duct of the body, C: Epididymal duct of the tail.

(NAGANO et al., 1994).

In addition to the peritubular myoid cells, smooth muscle-like contractile cells are also found in the tunica albuginea of the testis (HOLSTEIN, 1967; HOLSTEIN and WeISS, 1967; DAVIS and LANGFORD, 1970; HARGROVE et al., 1977). Contraction of the testicular capsule could also influence the movement of spermatozoa and fluid in the seminiferous tubule.

\section{Secretion of extracellular matrix components}

Peritubular myoid cells are in contact with the basal surface of the Sertoli cells. Both myoid cells and Sertoli cells are known to cooperate in the production and formation of a complex extracellular matrix (RAYCHOUDHURY et al., 1992, 1993; THOMPSON et al., 1995), providing structural integrity to the seminiferous tubule. It has been reported that myoid cells produce fibronectin (TUNG et al., 1984; SKINNER et al.,
1985), type I and IV collagens (SKINNER et al., 1985), and proteoglycans (SKINNER and FRITZ, 1985b). On the other hand, Sertoli cells have been demonstrated to produce laminin, type IV collagen (SKINNER et al., 1985; Borland et al., 1986; DAvis et al., 1990) and proteoglycans (SKINNER and FRITZ, 1985b). Basement membrane gene expression by myoid and Sertoli cells has also been examined in vitro in the rat (SKINNER et al., 1989c, d; RICHARDSON et al., 1995). HADLEY et al. (1985) have suggested that the extracellular matrix can influence the morphology of the Sertoli cell and the polarized secretion of Sertoli cell products in vitro.

\section{Secretion of growth factors}

In addition to the secretion of the extracellular matrix components, myoid cells also synthesize several secretory products. It has been demonstrated that the cells produce a paracrine factor, termed PModS (SKINNER 
and FrITZ, 1985a; SKINNER et al., 1988; NORTON and SKINNER, 1989), which modulates a number of Sertoli cell functions, such as the secretion of transferrin, inhibin, and androgen-binding protein (ABP) (SKINNER et al., 1989a, b). The actions of PModS on the Sertoli cell function appear to be more profound than FSH (SKINNER et al., 1988). Myoid cells also have been reported to secrete growth factors, such as transforming growth factor $\alpha$ (TGF $\alpha$ ) (SKINNER et al., 1989d), transforming growth factor $\beta$ (TGF $\beta$ ) (SKINNER and MOSES, 1989), insulin-like growth factor I (IGF-I) (CAILLEAU et al., 1990), and activin-A (DE WINTER et al., 1994). Reportedly, fibroblast growth factor (FGF) is immunolocalized in the human myoid cells (HoLSTEIN et al., 1996), and its receptor is expressed in the rat myoid cells (LE MAGUERRESSE-BATTISTONI et al., 1994). These factors presumably have regulatory roles important in the coordination of the complex process of spermatogenesis.

\section{Other possible functions}

Testosterone is known to regulate myoid cell function and differentiation (BRESSLER and ROSS, 1972; SKINNER and FRITZ, 1985a). However, KUROHMARU et al. (1990) reported that myoid cells from the golden hamster showed little morphometric change under depressed hormonal conditions induced by photoperiodic modifications, in contrast to marked alterations in both Sertoli and Leydig cells. Immunohistochemical studies have shown the existence of androgen receptors in myoid cells, Sertoli cells and Leydig cells in the rat testis (SAR et al., 1990; TAKEDA et al., 1990; BREMNER et al., 1994; VORNBERGER et al., 1994). In these cells, the androgen receptor mRNA is also detectable by in situ hybridization (SHAN et al., 1995). Androgens, produced by Leydig cells, are essential for the maintenance of spermatogenesis and the testicular function. Thus, androgen effects on the testicular function might partly be mediated by myoid cells.

Retinoids are essential for the maintenance of normal spermatogenesis. It has been demonstrated that myoid cells contain cellular retinol-binding protein (CRBP), but not cellular retinoic acid-binding protein (CRABP) (BLANER et al., 1987; FARAONIO et al., 1993). DAVIS and ONG (1995) have reported that rat myoid cells can internalize retinol in vitro. This suggests that myoid cells are involved in the processing of retinol.

Alkaline phosphatase activity is detected in the myoid cells of the rat (CHAPIN et al., 1987). This enzyme provides a useful histochemical marker, as well as the already discussed desmin, for investigation of the myoid cell function and differentiation (PALOMBI and
Di CARLO, 1988). Both testosterone and retinol appear to stimulate alkaline phosphatase activity in the rat myoid cell culture (ANTHONY and SKINNER, 1989).

Myoid cells also secrete an inhibitor of plasminogen activator (HETTLE et al., 1988), whereas Sertoli cells are known to produce plasminogen activator, one of the serine proteases (LACROIX et al., 1977; LACROIX and FRITZ, 1982). This is another example of cooperation between myoid cells and Sertoli cells, in addition to the secretion of the extracellular matrix and paracrine factors as indicated above. Myoid cells are involved in the control and maintenance of the Sertoli cell function and, therefore, may indirectly influence the process of spermatogenesis.

Further investigation into the myoid cell function is required to bring about a better understanding of this important cell type in the testis.

Acknowledgments. The authors thank Prof. T. UsHIKI (Niigata University) for providing us with the SEM micrograph shown in Figure 1. They also express their appreciation to Prof. K. FUKUDA (Chiba University) for the measurements of tubular pressure.

\section{REFERENCES}

Ailenberg, M., P. S. Tung and I. B. Fritz: Transforming growth factor- $\beta$ elicits shape changes and increases contractility of testicular peritubular cells. Biol. Reprod. 42: 499-509 (1990).

Anthony, C. T. and M. K. Skinner: Cytochemical and biochemical characterization of testicular peritubular myoid cells. Biol. Reprod. 40: 811-823 (1989).

Belkin, A. M. and V. E. Koteliansky: Interaction of iodinated vinculin, metavinculin and $\alpha$-actinin with cytoskeletal proteins. FEBS Lett. 220: 291-294 (1987).

Blaner, W. S., M. Galdieri and D. S. Goodman: Distribution and levels of cellular retinol and retinoic acid binding protein in various types of rat testis cells. Biol. Reprod. 36: 130-137 (1987).

Böck, P., G. Breitenecker and G. Lunglmayr: Kontraktile Fibroblasten (Myofibroblasten) in der Lamina propria der Hodenkanälchen vom Menschen. Z. Zellforsch. 133: 519-527 (1972).

Borland, K., K. E. Muffly and P. F. Hall: Production of components of extracellular matrix by cultured rat Sertoli cells. Biol. Reprod. 35: 997-1008 (1986).

Bremner, W. J., M. R. Millar, R. M. SharPe and P. T. K. SAUnders: Immunohistochemical localization of androgen receptors in the rat testis: evidence for stagedependent expression and regulation by androgens. Endocrinology 135: 1227-1234 (1994).

Bressler, R. S. and M. G. Ross: Differentiation of peritubular myoid cells of the testis: effects of intratesticular implantation of newborn mouse testes into normal and hypophysectomized adults. Biol. Reprod. 6: 
148-159 (1972).

Bustos-ObREgon, E.: Ultrastructure and function of the lamina propria of mammalian seminiferous tubules. Andrologia 8: 179-185 (1976).

Bustos-Obregon, E. and A. F. Holstein : On structural patterns of the lamina propria of human seminiferous tubules. Z. Zellforsch. 141: 413-425 (1973).

Bustos-Obregon, E. and M. Courot: Ultrastructure of the lamina propria in the ovine seminiferous tubule. Development and some endocrine considerations. Cell Tiss. Res. 150: 481-492 (1974).

Cailleau, J., S. Vermeire and G. Verhoeven: Independent control of the production of insulin-like growth factor I and its binding protein by cultured testicular cells. Mol. Cell. Endocrinol. 69: 79-89 (1990).

Carvalho, T. L. L., N. P. Hodson, M. A. Bland, P. F. Watson, P. K. Mulderry, A. E. Bishop, J. Gu, S. R. Bloom and J. M. Polak: Occrurrence, distribution and origin of peptide-containing nerves of guinea-pig and rat male genitalia and the effects of denervation on sperm characteristics. J. Anat. 149: 121-141 (1986).

Chapin, R. E., J. L. Phelps, B. E. Miller and T. J. B. GRAY: Alkaline phosphatase histochemistry discriminates peritubular cells in primary rat testicular cell culture. J. Androl. 8: 155-161 (1987).

Christensen, A. K.: Leydig cells. In: (ed. by) D. W. HAMilton and R. O. GREEP: Handbook of physiology: Endocrinology, Vol. 5, Sect. 7. Male reproductive system. American Physiological Society, Washington, D. C., 1975 (p. 57-94).

Christl, H.-W.: The lamina propria of vertebrate seminiferous tubules: A comparative light and electron microscopic investigation. Andrologia 22: 85-94 (1990).

Clermont, Y.: Contractile elements in the limiting membrane of the seminiferous tubules of the rat. Exp. Cell Res. 15: 438-440 (1958).

Crabo, B.: Fine structure of the interstitial cells of the rabbit testis. Z. Zellforsch. 61: 587-604 (1963).

DavidofF, M. S., H. Breucker, A. F. Holstein and K. SEIDL: Cellular architecture of the lamina propria of human seminiferous tubules. Cell Tiss. Res. 262: 253-261 (1990).

Davidoff, M. S., R. MiddendorfF, B. MaYer and A. F. HolsteIN : Nitric oxide synthase (NOS-1) in Leydig cells of the human testis. Arch. Histol. Cytol. 58: 17-30 (1995).

Davis, C. M., V. Papadopoulos, C. L. Sommers, H. D. KLEINMAN and M. DYM: Differential expression of extracellular matrix components in rat Sertoli cells. Biol. Reprod. 43: 860-869 (1990).

Davis, J. R. and G. A. LANGFord: Pharmacological studies of the testicular capsule in relation to sperm transport. In: (ed. by) E. RosemberG and C. A. PAULSEN: The human testis. Plenum, New York, 1970 (p. 495-514).

Davis, J. T. and D. E. ONG: Retinol processing by the peritubular cell from rat testis. Biol. Reprod. 52: 356364 (1995).

DE Winter, J. P., H. M. J. V ANderstichele, G. Verhoeven, M. A. Timmerman, J. G. Wesseling and F. H. DE
JoNG: Peritubular myoid cells from immature rat testes secrete activin-A and express activin receptor type II in vitro. Endocrinology 135: 759-767 (1994).

DyM, M.: The fine structure of the monkey (Macaca) Sertoli cell and its role in maintaining the blood-testis barrier. Anat. Rec. 175: 639-656 (1973).

DyM, M. and D. W. FAwCETT: The blood-testis barrier in the rat and the physiological compartmentation of the seminiferous epithelium. Biol. Reprod. 3: 308-326 (1970).

Faraonio, R., M. Galdieri and V. Colantuoni: Cellular retinoic-acid-binding-protein and retinol-binding-protein mRNA expression in the cells of the rat seminiferous tubules and their regulation by retinoids. Eur. J. Biochem. 211: 835-842 (1993).

FawcetT, D. W.: The architecture of the interstitial tissue of the testis and of cell junctions in the seminiferous tubule. Adv. Biosci. 10: 83-100 (1973).

Fawcett, D. W., P. M. Heidger and L. V. Leak: Lymph vascular system of the interstitial tissue of the testis as revealed by electron microscopy. J. Reprod. Fertil. 19: 109-119 (1969).

Fawcett, D. W., L. V. Leak and P. M. Heidger: Electron microscopic observations on the structural components of the blood-testis barrier. J. Reprod. Fertil. Suppl. 10: 105-122. (1970).

FawCett, D. W., W. B. Neaves and M. N. Flores: Comparative observations on the intertubular lymphatics and the organization of the interstitial tissue of the mammalian testis. Biol. Reprod. 9: 500-532 (1973).

Fay, F. S., K. Fujiwara, D. D. Rees and K. E. Fogarty : Distribution of $\alpha$-actinin in single isolated smooth muscle cells. J. Cell Biol. 96: 783-795 (1983).

Filippini, A., A. Tripiciano, F. Palombi, A. Teti, R. Paniccia, M. Stefanini and E. Ziparo: Rat testicular myoid cells respond to endothelin: characterization of binding and signal transduction pathway. Endocrinology 133: 1789-1796 (1993).

Gardner, P. J. and E. A. Holyoke: Fine structure of the seminiferous tubule of the Swiss mouse. I. The limiting menbrane, Sertoli cell, spermatogonia and spermatocytes. Anat. Rec. 150: 391-404 (1964).

Geiger, B., A. H. Dutton, K. T. Tokuyasu and S. J. SINGER: Immunoelectron microscope studies of membranemicrofilament interactions: distributions of $\alpha$-actinin, tropomyosin, and vinculin in intestinal epithelial brush border and chicken gizzard smooth muscle cells. J. Cell Biol. 91: 614-628 (1981).

Grove, B. D. and A. W. VogL: Sertoli cell ectoplasmic specializations: a type of action-associated adhesion junction? J. Cell Sci. 93: 309-323 (1989).

Grove, B. D., D. C. Pfeiffer, S. Allen and A. W. Vogl: Immunofluorescence localization of vinculin in ectoplasmic ("junctional") specializations of rat Sertoli cells. Amer. J. Anat. 188: 44-56 (1990).

Hadley, M. A., S. W. Byers, C. A. Suarez-Quian, H. K. KLEInMAN and M. DyM: Extracellular matrix regulates Sertoli cell differentiation, testicular cord formation, and germ cell development in vitro. J. Cell Biol. 101: 1511-1522 (1985). 
Hargrove, J. L., J. H. Macindoe and L. C. Ellis: Testicular contractile cells and sperm transport. Fertil. Steril. 28: 1146-1157 (1977).

Hettle, J. A., E. Balekjian, P. S. Tung and I. B. Fritz: Rat testicular peritubular cells in culture secrete an inhibitor of plasminogen activator activity. Biol. Reprod. 8: 359-371 (1988)

Holstein, A. F.: Die glatte Muskulatur in der Tunica albuginea des Hodens und ihr Einfluss auf den Spermatozoatransport in den Nebenhoden. Ergeb. Anat. Anz. 121: 103 (1967).

Holstein, A. F. and C. Weiss: Über die Wirkung der glatten Muskulatur in der Tunica albuginea in Hoden des Kaninchens; Messungen des intersitiellen Druckes. Z. Ges. Exp. Med. 142: 334-337 (1967).

Holstein, A. F. and E. C. Roosen-Runge: Atlas of human spermatogenesis. Grosse, Berlin, 1981

Holstein, A. F., M. Maekawa, T. Nagano and M. S. DAVidoff: Myofibroblasts in the lamina propria of human seminiferous tubules are dynamic structures of heterogeneous phenotype. Arch. Histol. Cytol. 59 (1996, in press).

Howl, J., S. A. Rudge, R. A. Lavis, A. R. L. Davies, R. A. Parslow, P. J. Hughes, C. J. Kirk, R. H. Michell and M. WheAtLeY: Rat testicular myoid cells express vasopressin receptors: receptor structure, signal transduction, and developmental regulation. Endocrinology 136: 2206-2213 (1995).

KerR, J. B., K. A. RICH and D. M. DE KretSER: Effect of experimental cryptorchidism on the ultrastructure and function of the Sertoli cell and peritubular tissue of the rat testis. Biol. Reprod. 21: 823-838 (1979).

Kohnen, G., M. Castellucci, B.-L. Hsi, C.-J. G. Yeh and P. KaUfmann: The monoclonal antibody GB42-a useful marker for the differentiation of myofibroblasts. Cell Tiss. Res. 281: 231-242 (1995).

Kormano, M. and O. HovatTa: Contractility and histochemistry of the myoid cell layer of the rat seminiferous tubule during postnatal development. Z. Anat. Entwickl. Gesch. 137: 239-248 (1972).

Kurohmaru, M., A. P. Sinha Hikim, A. Mayerhofer, A. BARTKE and L. D. RUSSEll: Golden hamster myoid cells during active and inactive states of spermatogenesis: correlation of testosterone levels with structure. Amer. J. Anat. 188: 319-327 (1990).

LACroix, M. and I. B. Fritz: The control of the synthesis and secretion of plasminogen activator by Sertoli cells in culture. Mol. Cell. Endocrinol. 26: 247-258 (1982).

LACroix, M., F. E. SMith and I. B. Fritz: Secretion of plasminogen activator by Sertoli cell-enriched cultures. Mol. Cell Endocrinol. 9: 227-236 (1977).

LACY, D. and J. Rotblat: Study of normal and irradiated boundary tissue of the seminiferous tubules of the rat. Exp. Cell Res. 21: 49-70 (1960).

Le Magueresse-Battistoni, B., J. Wolff, A.-M. Morera and M. BENAHMED: Fibroblast growth factor receptor type 1 expression during rat testicular development and its regulation in cultured Sertoi cells. Endocrinology 135: 2404-2411 (1994).
LeEson, C. R. and T. S. LeEson: The postnatal development and differentiation of the boundary tissue of the seminiferous tubule of the rat. Anat. Rec. 147: 243-259 (1963).

Leeson, C. R. and D. E. Forman : Postnatal development and differentiation of contractile cells within the rabbit testis. J. Anat. 132: 491-511 (1981).

Maekawa, M., T. Nagano, K. Kamimura, T. Murakami, H. Ishikawa and M. Dezawa: Distribution of actinfilament bundles in myoid cells, Sertoli cells, and tunica albuginea of rat and mouse testes. Cell Tiss. Res. 266: 295-300 (1991).

Maekawa, M., T. Nagano and T. Murakami: Comparison of actin-filament bundles in myoid cells and Sertoli cells of the rat, golden hamster and mouse. Cell Tiss. Res. 275: 395-398 (1994).

Maekawa, M., H. KaZama, K. Kamimura and T. NaGano: Changes in the arrangement of actin filaments in myoid cells and Sertoli cells of rat testes during postnatal development and after experimental cryptorchidism. Anat. Rec. 241: 59-69 (1995).

Martin, R., L. Santamaria, M. Nistal, B. Fraile and R. RANiAgUA: The peritubular myofibroblasts in the testes from normal men and men with Klinefelter's syndrome. A quantitative, ultrastructural, and immunohistochemical study. J. Pathol. 168: 59-66 (1992).

McCoRD, R. G.: Fine structural observations of the peritubular cell layer in the hamster testis. Protoplasma 69: 283-289 (1970).

Menkel, A. R., M. Kroemker, P. Bubeck, M. Ronsiek, G. NikolaI and B. M. JockUsCH: Characterization of an $\mathrm{F}$-actin-binding domain in the cytoskeletal protein vinculin. J. Cell Biol. 126: 1231-1240 (1994).

MiYake, K., M. Yamamoto, H. Narita, J. Hashimoto and H. MitsUY A : Evidence for contractility of the human seminiferous tubule confirmed by its response to noradrenaline and acetylcholine. Fertil. Steril. 46: 734-737 (1986).

Moone, C. R.: Properties of the gonads as controllers of somatic and psychial characteristics. VI. Testicular reactions in experimental cryptorchidism. Amer. J. Anat. 34: 269-316 (1924).

Murakami, M., M. Hamasaki, S. Okita and J. Abe: SEM surface morphology of the contractile cells in the rat seminiferous tubules. Experientia 35: 1099-1100 (1979).

Nagano, T., M. Maekawa, Y. Fukuda and T. Murakami: Morphological studies on the wall components of seminiferous and epididymal tubules in rodents in relation to their movements. In: (ed. by) T. MorI, T. AONO, T. TominAGA and M. HiroI: Perspectives on assisted reproduction. Ares-Serono Symposia Publications, Rome, 1994 (p. 129-135).

NiEmi, M. and M. Kormano: Contractility of the seminiferous tubule of the postnatal rat testis and its response to oxytocin. Ann. Med. Exp. Fenn. 43: 40-42 (1965).

Norton, J. N. and M. K. SkinNer: Regulation of Sertoli cell function and differentiation through the actions of a testicular paracrine factor PModS. Endocrinology 124: 2711-2719 (1989). 
Palombi, F. and C. Di Carlo: Alkaline phosphatase is a marker for myoid cells in cultures of rat peritubular and tubular tissue. Biol. Reprod. 39: 1101-1109 (1988).

Palombi, F., D. Farini, M. Salanova, S. Degrossi and M. Stefanini: Development and cytodifferentiation of peritubular myoid cells in the rat testis. Anat. Rec. 233: 32-40 (1992).

Paranko, J. and L. J. Pelliniemi: Differentiation of smooth muscle cells in the fetal rat testis and ovary: localization of alkaline phosphatase, smooth muscle myosin, F-actin, and desmin. Cell Tiss. Res. 268: 521-530 (1992).

Pickering, B. T., S. D. Birkett, S. E. F. GuldenaAr, H. D. Nicholson, R. T. S. Worley and L. YAVACHEV: Oxytocin in the testis: what, where and why? Ann. New York Acad. Sci. 564: 189-209 (1989).

Raychoudhury, S. S., M. G. Irving, E. W. Thompson and A. W. Blackshaw: Collagen biosynthesis in cultured rat testicular Sertoli and peritubular myoid cells. Life Sci. 51: 1585-1596 (1992).

Raychoudhury, S. S., A. W. Blackshaw and M. G. IRVING: Hormonal modulation of the interactions of cultured rat testicular Sertoli and peritubular myoid cells: effects on glycosaminoglycan synthesis. J. Androl. 14: 9-16 (1993).

REgaud, C.: Études sur la structure des tubes séminifères et sur la spermatogénèse chez les mammifères. Arch. Anat. Microsc. 4: 101-155 (1901).

Richardson, L. L., H. K. Kleinman and M. Dym: Basement membrane gene expression by Sertoli and peritubular myoid cells in vitro in the rat. Biol. Reprod. 52: 320-330 (1995).

Roosen-Runge, E. C.: Motions of the seminiferous tubules of rat and dog. Anat. Rec. 109: 413 (1951).

Ross, M. H.: The fine structure and development of the peritubular contractile cell component in the seminiferous tubules of the mouse. Amer. J. Anat. 121: 523-557 (1967).

Ross, M. H. and I. R. LoNG: Contractile cells in human seminiferous tubules. Science 153: 1271-1273 (1966).

Rothwell, B. and M. D. Tingari: The ultrastructure of the boundary tissue of the seminiferous tubule in the testis of the domestic fowl (Gallus domesticus). J. Anat. 114: 321-328 (1973).

Russell, L. D., A. Bartke and J. C. GOH: Postnatal development of the Sertoli cell barrier, tubular lumen, and cytoskeleton of Sertoli and myoid cells in the rat, and their relationship to tubular fluid secretion and flow. Amer. J. Anat. 184: 179-189 (1989).

Sar, M., D. B. Lubahn, F. S. French and E. M. Wilson: Immunohistochemical localization of the androgen receptor in rat and human tissues. Endocrinology 127: 3180-3186 (1990).

Schlatt, S., G. F. Weinbauer, M. Arslan and E. Nieschlag: Appearance of $\alpha$-smooth muscle actin in peritubular cells of monkey testes is induced by androgens, modulated by follicle-stimulating hormone, and maintained after hormonal withdrawal. J. Androl. 14: 340-350 (1993).
ShaN, L.-X., L.-J. ZHU, C. W. BARdIN and M. P. HARDY : Quantitative analysis of androgen receptor messenger ribonucleic acid in developing Leydig cells and Sertoli cells by in situ hybridization. Endocrinology 136: 38563862 (1995)

Skinner, M. K. and I. B. Fritz: Testicular peritubular cells secrete a protein under androgen control that modulates Sertoli cell function. Proc. Nat. Acad. Sci. USA 82: 114-118 (1985a).

- : Structure characterization of proteoglycans produced by testicular peritubular cells and Sertoli cells. J. Biol. Chem. 260: 11874-11883 (1985b).

Skinner, M. K. and H. L. Moses: Transforming growth factor-beta gene expression and action in the seminiferous tubule: peritubular cell-Sertoli cell interactions. Mol. Endocrinol. 3: 625-634 (1989).

Skinner, M. K., P. S. Tung and I. B. Fritz: Cooperativity between Sertoli cells and testicular peritubular cells in the production and deposition of extracellular matrix components. J. Cell Biol. 100: 1941-1947 (1985).

Skinner, M. K., P. M. Fetterolf and C. T. Anthony: Purification of a paracrine factor, P-Mod-S, produced by testicular peritubular cells that modulates Sertoli cell function. J. Biol. Chem. 263: 2884-2890 (1988).

Skinner, M. K., R. I. MClachlan and W. J. BREMER: Stimulation of Sertoli cell inhibin secretion by the testicular paracrine factor PModS. Mol. Cell. Endocrinol. 66: 239-249 (1989a).

Skinner, M. K., S. M. Schlitz and C. T. Anthony: Regulation of Sertoli cell differentiated function: testicular transferrin and androgen-binding protein expressin. Endocrinology 124: 3015-3024 (1989b).

Skinner, M. K., B. Stallard, C. T. Anthony and M. D. GRISWOLD: Cellular localization of fibronectin gene expression in the seminiferous tubule. Mol. Cell. Endocrinol. 66: 45-52 (1989c).

Skinner, M. K., K. TaKaCs and R. J. CoffeY: Cellular localization of transforming growth factor-alpha gene expression and action in the seminiferous tubule: peritubular cell-Sertoli cell interactions. Endocrinology 124: 845-854 (1989d).

Steger, K., M. Shimmel and K.-H. Wrobel: Immunocytochemical demonstration of cytoskeletal proteins in seminiferous tubules of adult rams and bulls. Arch. Histol. Cytol. 57: 17-28 (1994).

Suvanto, 0. and M. Kormano: The relation between in vitro contractions of the rat seminiferous tubules and the cyclic stage of the seminiferous epithelium. J. Reprod. Fertil. 21: 227-232 (1970).

Takeda, H., G. Chodak, S. Mutchnik, T. Nakamoto and C. Chang: Immunohistochemical localization of androgen receptors with mono- and polyclonal antibodies to androgen receptor. J. Endocrinol. 126: 17-25 (1990).

Thompson, E. W., A. W. BlaCkSHAW and S. S. RaYChOUdHURY: Secreted products and extracellular matrix from testicular peritubular myoid cells influence androgenbinding protein secretion by Sertoli cells in culture. J. Androl. 16: 28-35 (1995). 
Toyama, Y.: Actin-like filaments in the myoid cell of the testis. Cell Tiss. Res. 177: 221-226 (1977).

TUNG, P. S. and I. B. Fritz: Characterization of rat testicular peritubular myoid cells in culture: $\alpha$-smooth muscle isoactin is a specific differetiation marker. Biol. Reprod. 42: 351-365 (1990).

Tung, P. S., M. K. Skinner and I. B. Fritz: Fibronectin synthesis is a marker for peritubular cell contaminants in Sertoli-enriched cultures. Biol. Reprod. 30: 199-211 (1984).

UNSICKER, K: Fine structure of the male genital tract and kidney in the anura Xenopus laevis Daudin, Rana temporaria L. and Bufo bufo L. under normal and experimental conditions. I. Testicular interstitial tissue and seminal efferent ducts. Cell Tiss. Res. 158: 215-240 (1975).

Unsicker, K. and G. Burnstock: Myoid cells in the peritubular tissue (Lamina propria) of the reptilian testis. Cell Tiss. Res. 163: 545-560 (1975).

Van Nassauw, L., F. Harrison and M. Callebaut: Smooth muscle cells in the peritubular tissue of the quail testis. Eur. J. Morphol. 31: 60-64 (1993).

Virtanen, L., M. Kallajoki, O. Narvanen, J. Parando, L. E. Thornell, M. Miettinen and V. P. Lehto: Peritubular myoid cells of human and rat testis are smooth muscle cells that contain desmin-type intermediate filaments. Anat. Rec. 215: 10-20 (1986).

VoGL, A. W.: Distribution and function of organized concentrations of actin filaments in mammalian spermatogenic cells and Sertoli cells. Int. Rev. Cytol. 119: 1-56 (1989).

Vogl, A. W. and L. J. Soucy: Arrangement and possible function of actin filament bundles in ectoplasmic specializations of ground squirrel Sertoli cells. J. Cell Biol. 100: 814-825 (1985).
VogL, A. W., L. J. SoucY and G. J. Lew: Distribution of actin in isolated seminiferous epithelia and denuded tubule walls of the rat. Anat. Rec. 213: 63-71 (1985).

Vornberger, W., G. Prins, N. A. Musto and C. A. SUAREZ-QUIAN: Androgen receptor distribution in rat testis: new implications for androgen regulation of spermatogenesis. Eodocrinology 134: 2307-2316 (1994).

W AChsstock, D. H., J. A. Wilkins and S. LiN : Specific interaction of vinculin with $\alpha$-actinin. Biochem. Biophys. Res. Commun. 146: 554-560 (1987).

Wrobel, K.-H., R. Mademann and F. Sinowatz: The lamina propria of the bovine seminiferous tubule. Cell Tiss. Res. 202: 357-377 (1979).

Wrobel, K.-H., S. Dostal and M. Schimmer: Postnatal development of the tubular lamina propria and the intertubular tissue in the bovine testis. Cell Tiss. Res. 252: 639-653 (1988).

Yamamoto, M., J. Hashimoto, H. Takaba and $\mathbf{K}$. MIYAKE: Response of the isolated human seminiferous tubule to prostaglandins $\mathrm{F}_{1} \alpha, \mathrm{F}_{2} \alpha, \mathrm{E}_{1}$ and $\mathrm{E}_{2}$. J. Urol. 137: 345-348 (1987).

Dr. Mamiko MaEKAWA

Department of Anatomy Chiba University School of Medicine Inohana, Chuo-ku, Chiba 260 Japan

前川畺見子

260 千葉市中央区亥鼻 1-8-1

千葉大学医学部

解剖学第二講座 